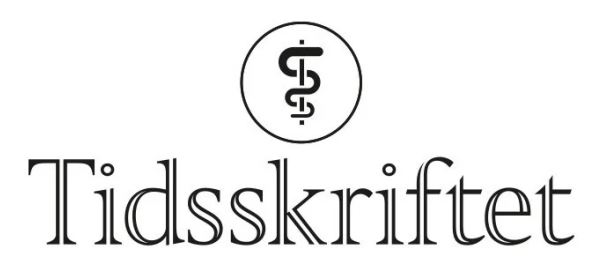

DEN NORSKE LEGEFORENING

\title{
P. Aavitsland svarer:
}

BREV TIL REDAKTØREN

PREBEN AAVITSLAND

Folkehelseinstituttet

I lederartikkelen konkluderte jeg slik: «Stoffmisbrukere har, som andre borgere, krav på den beste behandling vi kan tilby. Men de må få god informasjon om valgene. En asymptomatisk infeksjon med hepatitt C-viruset er for de fleste antakelig et av de minste problemene de sliter med. For dem kan det beste valget være å vente med behandling til de har løst en del andre helseproblemer og livsvansker. I mellomtiden er kanskje behandlingen også blitt mer effektiv, mindre farlig og bedre dokumentert. Og helsetjenesten kan bruke ressursene på andre av misbrukernes helseproblemer» (11).

En stoffmisbruker i rehabilitering kan ha mange livsvansker og helseproblemer å rydde opp i, knyttet til f.eks. jobb, tannhelse, bolig, ernæringsstatus, hudsår og psykisk sykdom. Sammen med fastlegen sin kan vedkommende ta for seg disse problemene ett for ett. Da er det ikke sikkert at behandling av en HCV-infeksjon uten leveraffeksjon skal stå øverst på listen.

Dalgard \& Skrede har dermed ikke dekning for å hevde at jeg synes at «opiatavhengige stort sett bør ikke bør få behandling for hepatitt C-virusinfeksjon». Jeg mener, som Dalgard

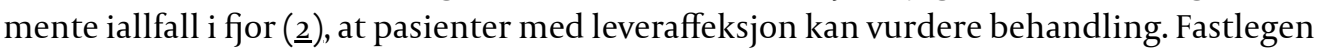
kan altså følge sine pasienter og henvise dem som er motivert for behandling ved vedvarende forhøyede transaminaser ( $>35$ for kvinner og $>50$ for menn) $(\underline{2})$.

Nå ser det ut til at Dalgard \& Skrede, Krook og Kristensen og medarbeidere vil behandle også dem uten leveraffeksjon. Da må de dokumentere at dette er til fordel for pasientene, gitt infeksjonens stort sett godartede naturlige forløp uten behandling (3). Dalgards ukontrollerte behandlingsstudie fra $2004 \mathrm{og}$ hans tverrsnittsstudie fra 2003 sier lite om langtidsprognosen ved hepatitt C-virusinfeksjon. Som sykehusleger møter Dalgard \& Skrede de som har leversykdom, ikke de tusenvis av leverfriske hepatitt C-infiserte. Pasientene og fastlegene må ha et mer avansert syn på sykdommens naturlige forløp, og det kan de få fra kohortstudier som følger grupper av pasienter fra smittetidspunktet (3). En retrospektiv kohortstudie (4) som viste bedre overlevelse hos leversyke som hadde fått behandling, sier lite om behandlingsnytten for leverfriske hepatitt C-smittede.

Jeg er enig med Krook i at stigmatisering av hepatitt C-smittede må unngås og at legene må skille mellom vedvarende infeksjon (positiv HCV-RNA) og gjennomgått infeksjon (antistoffer, men vedvarende negativ HCV-RNA). 
1. Aavitsland P. Er hepatitt C viktig for stoffmisbrukerne? Tidsskr Nor Legeforen 2009; 129: 1623.

2. Vik IS, Skaug K, Dalgard O et al. Hepatitt C - et helseproblem også i Norge. Tidsskr Nor Legeforen 2008; $128: 563-6$.

3. Seeff LB. The history of the «natural history» og hepatitis C (1968-2009). Liver Int 2009; 29 (suppl 1): 89-99.

4. Yoshida $\mathrm{H}$, Arakawa Y, Sata M et al. Interferon therapy prolonged life expectancy among chronic hepatitis C patients. Gastroenterology 2002; 123: 483-91.

Publisert: 3. desember 2009. Tidsskr Nor Legeforen. DOI: 10.4045/tidsskr.09.1125

(C) Tidsskrift for Den norske legeforening 2023. Lastet ned fra tidsskriftet.no 26. april 2023. 